
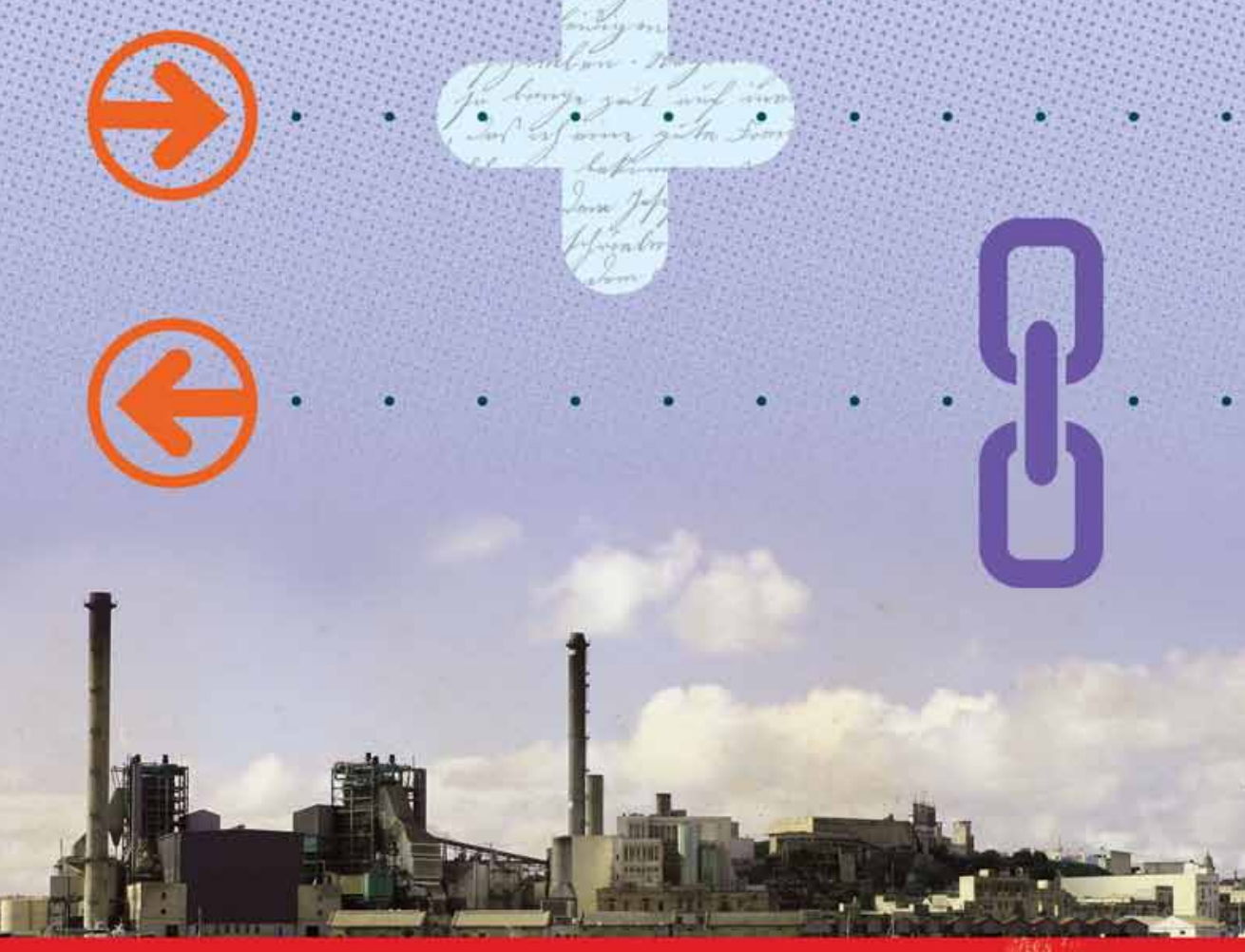


\title{
Emerging and hybrid: the cases of turkish and brazilion market economies
}

\author{
Emergente e Híbrido: os casos das \\ economias de mercado de Turquia e Brasil
}

Isik Ozel

\begin{abstract}
Resumo
Este artigo examina as maneiras em que a economia de mercado turca evoluiu para uma forma híbrida marcado por características nãoliberais. Explorando a dinâmica de continuidade e mudança em termos de configurações institucionais, o artigo analisa algumas das principais tensões entre as instituições antigas e novas nesta economia de mercado emergente, que atingiu níveis notáveis de crescimento na última década, mesmo no contexto do curso de crise global. Estabelece comparações entre a Turquia e o Brasil sobre o surgimento de variedades híbridas de capitalismo na transição do desenvolvimento liderado pelo Estado aos processos de abertura de mercado. $\mathrm{O}$ artigo afirma que, comparado com o seu homólogo brasileiro, a economia de mercado turca é mais próxima de economias de mercado patrimoniais e estatista, mais do que os liberais, e quase que constantemente passa por uma vacilação entre institucionalização e desinstitucionalização.
\end{abstract}

Palavras-chave: Variedades de capitalismo, transições de mercado, economia de mercado liberal, Turquia, Brasil, BRICs

\begin{abstract}
This article examines the ways in which Turkish market economy has evolved into a hybrid form marked by illiberal characteristics. Exploring the dynamics of continuity and change in terms of institutional configurations, the article analyzes some of the major tensions between the old and new institutions in this emerging market economy which has attained remarkable levels of growth within the last decade even in the context of the ongoing global crisis. It draws comparisons between Turkey and Brazil regarding the emergence of hybrid varieties of capitalism in the transition from state-led development to market opening processes. The article asserts that compared to its Brazilian counterpart, the Turkish market economy is closer to patrimonial and statist market economies, rather than the liberal ones, and almost constantly goes through a vacillation between institutionalization and de-institutionalization.
\end{abstract}

Key Words: Varieties of capitalism, market transitions, illiberal market economy, Turkey, Brazil, BRICS 


\section{Introduction}

Turkish market economy and its evolution in the last few decades can be characterized by the coexistence of continuity and change. The interactions between the old and the new along with the dynamics of transition have given rise to a combination of varieties of capitalism in this emerging country with daring aspirations to be placed in the first league soon. Despite the institutional changes and substantial reforms recently introduced into varying policy areas, some patterns of governance inherited from the "old regime" still prevail. Embarking upon a hybrid form, the Turkish market economy has a generally illiberal character and it can be situated between patrimonial, statist and hierarchical varieties of capitalism construed for emerging countries (Becker 2011, Schneider 2009). These varieties deviate considerably from the two major categories offered by Hall and Soskice (2001), namely liberal and coordinated market economies. The following sections will examine the processes through which Turkish market economy has adopted its hybrid form by focusing on several dimensions such as corporate governance and state-capital relations; statelabor relations; social policy; and privatization. This study will examine some of the significant transformations which have taken place in these dimensions throughout the multifaceted market transitions since the 1980s.

Although the study mainly draws on Turkey, it also aims to situate Turkey within the group of emerging countries, more importantly the BRICs (Brazil, Russia, India and China), with respect to the configuration of market economies. Amongst the emerging countries, Turkish market economy displays striking similarities with that of Brazil particularly regarding its relatively longer capitalistic experience marked with state-led development strategies as well as market transitions still maneuvered by the respective states (Boschi and Santana 2012). This study, then, carries out some comparisons between Turkey and Brazil, two emerging countries considered to play leadership roles in their respective regions in the context of an ongoing global crisis which triggered burgeoning trajectories for multipolar globalization. Both countries have experienced a noteworthy economic growth as well as political stability within the last decade, enabling them to make claims about wide-ranging global issues beyond the scope of their respective hinterlands. Despite their ideological differences, the incumbents in both countries have vacillated between embracing globalization and confronting it-particularly regarding power asymmetries embedded in the international and regional organizations. Tackling the initial skepticism of the international organizations and the investors alike, the leaders elected to embark upon incumbency in 2002, namely Luiz Inacio Lula da Silva and Recep Tayyip Erdogan, have signaled the international and domestic players that they would conform with the rules of the ongoing globalization process and their identities as a union leader and a former disciple of pro-Islamist movements respectively would not thwart their commitment for further integrating their countries to the global markets. In spite of 
such unanticipated conformity with the prevalent rules of global integration, they both have not evaded posing bold challenges against some of those rules, which, in fact, increased their popularity further not only at home, but also in their respective regions.

Swinging in a pendulum as a developing country being involved in some of the major clubs of the advanced countries, such as the OECD, Turkey is now considered an upper-middle-income country, one of the G-20, with a fairly developed industrial base, akin to the BRICs. Following a belated "lost decade" in the 1990s, the Turkish economy has had a striking performance in the first decade of the $21^{\text {st }}$ century. Institutional reforms mostly undertaken in the aftermath of the 2000-2001 economic crises have played an important role in facilitating the recent performance and relative resilience of the economy to the current global crisis. By attaining an annual growth rate of $7.2 \%$ between 2002 and 2007, the GDP reached $\$ 735$ billion, making Turkey the $16^{\text {th }}$ largest economy in the world. ${ }^{1}$ Ranking the sixth largest in Europe, Turkish economy is only situated in the ranks of upper-middle-income countries with a GDP per capita of $\$ 10,094$, while that of Brazil is $\$ 10,710$ (2010 figures). ${ }^{2}$ Chart 1 below displays the income levels in selected emerging countries, while Chart 2 demonstrates almost parallel changes in those levels in Turkey and Brazil since 1960.

Despite the drastic changes which have taken place since the 1980s, market economies in the emerging countries, including those of Brazil and Turkey, are fairly different from those of the advanced countries. In their canonical study on varieties of capitalism, Hall and Soskice (2001:19) construct two varieties: liberal market economies where market mechanisms maintain coordination in financial and industrial relations, and coordinated market economies where non-market coordination prevails. In this study examining the varieties of capitalism within the OECD countries, Turkey, along

Chart 1. GDP Per Capita, Selected Emerging Countries (USD, 2010)

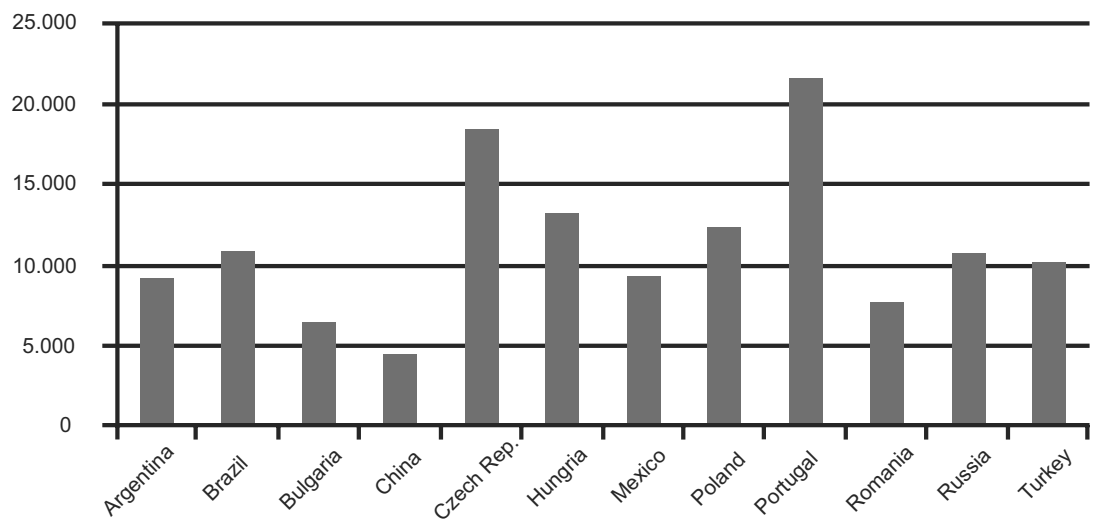

Source: World Development Indicators database, World Bank 
Chart 2. GDP per capita in Turkey and Brazil, 1960-2010 (USD)

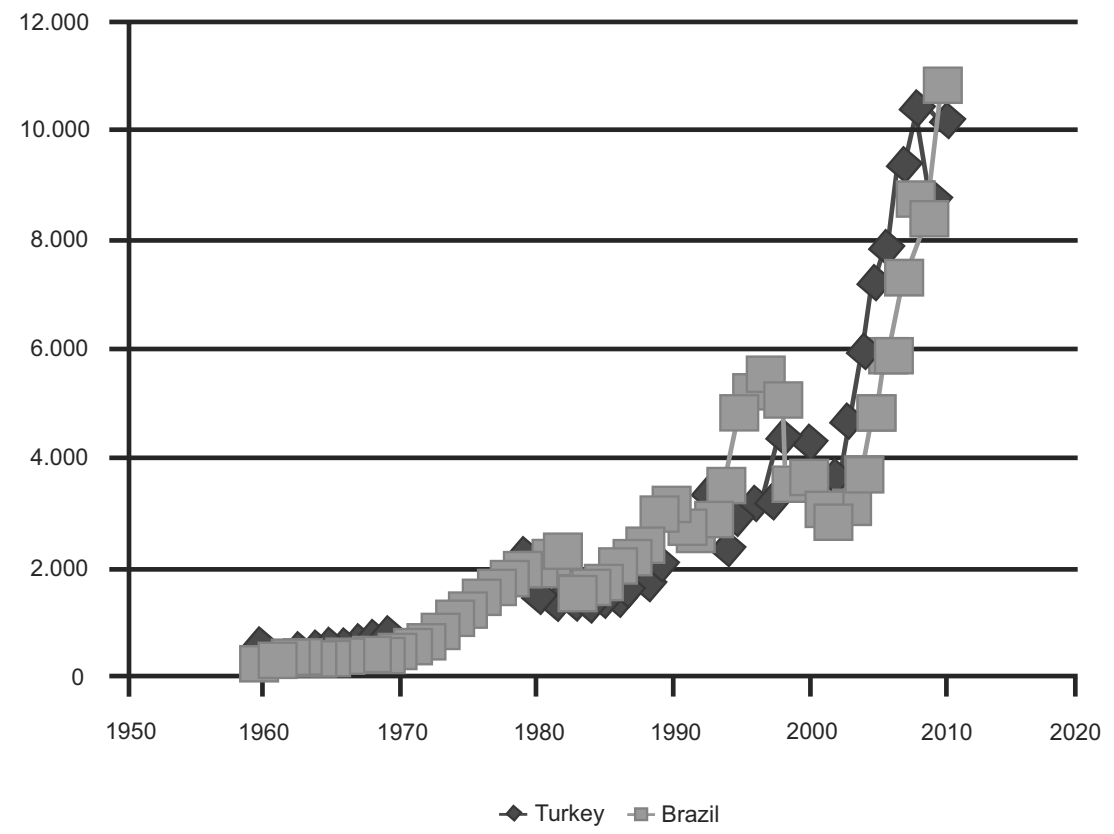

Source: World Development Indicators database, World Bank

with France, Italy, Portugal and Greece are considered to have ambiguous positions, yet clustered into "Mediterranean" variety where different forms of non-market coordination prevail in the existence of extensive state intervention and a large agrarian sector. In an effort to disaggregate this fuzzy category of Mediterranean, this study asserts that Turkish variety of capitalism can be analyzed through the tools offered by a newly emerging wave of literature on the varieties of capitalism in emerging countries (Becker 2011, Boschi and Santana 2012).

Among the BRICS, Turkish variety of capitalism is closer to that of Brazil. As Becker (2011: 10) argues, "patrimonialism penetrates capitalism strongly in all emerging political economies" and Turkey and Brazil are no exceptions in that albeit in varying extents. Becker (2011:11-12) delineates patrimonial variety by the significant role of political leadership and prevalence of patron-client relationships between the state and the market, while he conceptualizes statism as the state's dominant role over the economy where market regulation is restricted by political regulation, and hierarchical organization of firms coexists with limited worker rights. In terms of its institutional constellations particularly regarding the state's complex impact on the market players and mechanisms as well as maintained political control over the market forces, Turkish market economy can be situated between patrimonial and statist varieties of 
capitalism. Brazilian market economy also has a hybrid character, but it also entails certain characteristics of liberal market economy, in addition to patrimonial and statist types (Boschi 2011). Despite transformations taking place in Turkey since the 1980s, most important of which being the state's diminishing role in economic activities, some of the former patterns such as the prevalence of clientelistic networks and widespread patronage distribution are preserved (Birtek and Toprak 2011, GüneşAyata 1994, Roniger 2004, Stokes 2009). Hence, market liberalization coexists with old institutions and norms, while the former is often molded by the latter and the Turkish market economy mostly sustains illiberal and hierarchical character (Levi-Faur 2011, Schneider 2009).

\section{Turkey and Brazil: candidates for the most-similar-cases- analysis?}

Resemblance between Turkey and Brazil is not limited to income levels across time, but also entails parallel processes and almost simultaneous transitions marked by significant ruptures and continuities. For instance, the military played a substantial role not only in politics in both cases, but also in the respective markets along with development strategies and market transitions. It became a major economic actor in both countries through investing in various sectors and engaging in complex transactions with broad range of economic actors. Despite democratization which entailed the military's retreat from politics in its essence, the military's role in the market has been mostly retained as a "sticky legacy" in both Turkey and Brazil.

In both countries, the military interventions created significant ruptures which have given rise to major changes in institutions and policies. Contrary to Brazil's long-lasted military rule (1964-1985), there were four relatively-short-lived interventions in Turkey (1960-61, 1971, 1980-83, 1997). These interventions undertaken during severe fiscal and balance of payments crises brought about strict measures for macroeconomic stabilization-at least initially. More importantly, they provided available grounds for common use of extra-constitutional and executive decrees. Hence, one of the most important legacies of these ruptures is the power of the executive which has been even enhanced following the end of the military rule, since it was institutionalized by the 1982 Constitution in Turkey, and 1988 Constitution in Brazil. Although Turkey has a parliamentary system, the widespread use of executive discretion which has further intensified in recent years has brought about a system which nearly hosts de-facto presidentialism as further explained below.

As two middle-income countries which have fairly developed industrial bases, Turkey and Brazil went through almost simultaneous junctures throughout the twentieth century with respect to their development strategies and transitions. After having implemented import substitution industrialization strategy (ISI) for about five decades, in the 1980s these two countries began to open up coupled with the 
process of re-democratization. Like Brazil, Turkish experience with the ISI also included temporary attempts to open-up starting from the late 1950s. In fact, akin to other midincome countries with large domestic markets, Brazil and Turkey had considerable success with the ISI strategy in the 1960s and early 1970 s on varying levels. Although the "success" of the ISI strategy in Turkey was not as impressive as in Brazilian "economic miracle" (1968-1978) in the context of the Second National Plan of Development (19741979) due to the earlier emergence of foreign exchange-cum-debt crisis in Turkey right after the first oil crisis in 1973, the second phase of the ISI which entailed heavy industries had already been launched in both countries by the 1970s (Barkey 1990, Bresser-Pereira 1990). Both countries plunged into severe debt crises starting from the 1970 s, similar to many developing countries in the context of increasing liquidity in the 1970s, followed by increasing interest rates.

In the aftermath of these crises, Turkey launched a thorough market reform program in 1980, making the country one of the forerunners of the market reform process. Brazil's program was initiated in 1985 and broad range of market reforms including stabilization, liberalization and privatization have been implemented in both countries with differing levels of effectiveness in different time periods. In both cases, the market transitions were implemented under the auspices of the international financial institutions (IFIs) and both received hefty IFI loans in different time periods. In addition to bowing to the overall pressure of globalization to open up, Turkey and Brazil also made simultaneous commitments to major regional trade blocs: the MERCOSUR in the case of Brazil (1991) and the Customs Union Agreement with the European Union in the case of Turkey (1995).

In both countries, domestic industry was nurtured by the state within the context of a state-led development strategy originally initiated in the 1930s coinciding with the formation of major state institutions in the context of Vargas' and Atatürk's increasingly authoritarian regimes entailing various elements of corporatism, populism and cooptation under the banner of intensifying nationalism. State's increasing interventionism in domestic markets began in this period coinciding with the establishment of the Estado Novo in Brazil, and the new Republic in Turkey (Bresser-Pereira 1990, Keyder 1987). Both countries became the epitomes of state interventionism for most of the twentieth century: State-owned enterprises were established in various sectors, fast-track industrialization became the central goal of which the military was the most-committed actor not only with respect to the dispersion of a nationalistic discourse, but its control over economic resources and complex interactions with the private actors. Accordingly, domestic industry was nurtured by the state, as the state-led ISI regime prioritized industrialists in both countries, providing them with a broad range of selective incentives and granting privileged access to state authorities. The result of such nurturing has been a high level of capital concentration and large conglomerates with multi-sectoral investment-as the dominant corporate structure within big business. Implicit pacts between the 
states and industrialists - particularly the large conglomerates-were formed, the former providing rents to the latter through personal or organizational contacts; and the latter avoiding challenging the regime (Amann \& Baer, 2008 Barkey 1990, Kingstone 1999) and these pacts were sustained up until the 1980s. In both Brazil and Turkey, the state's control of societal interests-including those of the businesses-mostly prevailed as a common practice for decades, but this control was accompanied by a tactful use of redistributive strategies, including the formation of large patronage networks through which varying degrees and forms of rents were distributed.

Contrary to the common discourse which depicts the Brazilian and Turkish states as strong, I argue that strength tends to be conflated with interventionism and, at times, with authoritarianism. Both states suffered from limited capacities throughout most of the $20^{\text {th }}$ century, though they maintained heavy interventionism in the respective markets. Despite the widespread--and highly effective-distribution of patronage, these states could not generally negotiate with the society. I suggest that in time, the Brazilian state's capacity has increased at a much higher degree than that of the Turkish state which has kept its interventionism in varying forms coupled with authoritarianism, a process which has recently been on the rise (Boschi 2011, Boschi and Santana 2012, Ozel forthcoming). Thus, the Turkish state has maintained an illiberal character which also shapes the Turkish market economy which is subject to enhanced political control despite the three-decades-long liberalization process.

\section{An overview of economic transformations in Turkey}

As in several other middle-income countries including Brazil, state-led development in Turkey began in the 1930s and further institutionalized in the 1950s, and last until the 1980s. Then, Turkey became one of the first developing countries that implemented market reforms in the early 1980s following Chile and Argentina which had begun their market transitions in the 1970s. Although the transformations are usually referred to as market liberalization, Turkish market economy cannot be considered as liberal. The state often intervenes in the market as well as in institutions, organizations and actors based on the alleged objective of "enhancing the common interest." Indeed, the Turkish case denotes a large space of intersection between patrimonial and statist varieties of the MEs. It entails tensions between institutional legacies and the newly transplanted institutions, at times, impairing the effectiveness of new institutions. This section will provide an overview of economic transformations that the Turkish market economy has gone through in the last three decades.

The process of economic reforms in Turkey has taken a highly protracted path given the legacy of an interventionist-cum-authoritarian state and resistance by the existing institutions along with the interests entrenched in those. Interventionism and authoritarianism in different forms still affects governance despite the country's long path towards democratization. The excessive use of executive discretion has become 
common practice since the 1980 s, as it was facilitated by the 1982 Constitution, which institutionalized the executive's bypassing the legislature. ${ }^{3}$ The 1982 amendments enable the executive "share" legislative power although the $7^{\text {th }}$ Article of the Constitution strictly prohibits the delegation of legislative power, exemplifying "parliamentarism without a parliament" (Karahanoğulları 1998). Interestingly enough, some of the most important rules and policies about economic governance have been established by executive decrees since the 1980s, shaping the major turning points in the Turkish political economy. Bypassing the existing rules, actors and agents with actual or potential capacity for resistance has been a prevalent practice in Turkey and it has particularly marked the process of economic transformations since the 1980s. The thin base of the pro-reform coalition, particularly in the beginning of reforms, along with the available ground provided by the Constitution escorted reforming governments into this pragmatic path through which major turning points of the Turkish political economy have been shaped through bypassing democratic processes. This legacy of short-cut problem-solving includes by-passing the constraints (or resistance posed by bureaucrats, politicians, and private actors alike) through making new rules and organizations whenever the old ones do not cooperate in a manner desired by the executive (Öniş 2004, Ozel 2003 and 2012). Combined with the legacy of politicization of bureaucracy, such pragmatism resulted in an oscillating pattern between institutionalization and de-institutionalization by a constant change of rules and procedures, which has marked the market reform process since the $1980 \mathrm{~s}$.

\section{Antecedents of transformations}

Right after Turkey's launching of state-led development path in the 1930s accompanied by increasing authoritarianism, its geopolitical positioning in the context of the Cold War brought about the tutelage of the U.S. and the country got incorporated into the capitalistic Western bloc as a close ally starting from the 1940s. It then became a founding or early member of major multilateral organizations which set the post-war international order, the Bretton Woods trio as well as the OECD and the NATO. Turkey has also been striving to become a member of the EU for over five decades since the 1950s, and accession negotiations started in 2005, while the Customs Union Agreement was signed in 1995.

Nevertheless, Turkey's close alliance with the free market economies of the Western bloc did not stop heavy state intervention and market distorting policies and practices as price controls, a protectionist international trade regime, and strict barriers to international capital movements, at least until the beginning of the 1980s. Turkish state-led-capitalism, which had begun in the 1930s, entailed etatism which was placed in the Constitution in 1937, giving rise to large state investments which employed more than half of the workforce in the late 1970s (Waterbury 1993) besides providing cheap inputs and credits for private industry. 
Akin to Brazil's experience with ISI, Turkey's was fairly positive with a high rate of growth in GDP (5-6\%) until the early 1970s when the resource-dependent-economy was severely hit by, first, the oil crises and, then, the debt crisis. These shocks bolstered a devastating inflationary cycle and accompanying recession, succumbing the Turkish economy into a deep foreign exchange crisis, hobbling its import capacity and causing widespread shortages, resulting in a triple-digit inflation rate rising from 20\% in 1977 to $100 \%$ in 1980 (Kazgan 2004, Rodrik 1991). Political chaos followed course, resulting in an impasse in the parliament that gridlocked the presidential elections in 197980. Socio-political tension was substantial: the country was highly polarized, armed groups from the extreme left and right engaged in assaults, assassinations; clashes between extremist groups and the state's security forces intensified, paralyzing governments' attempts at stabilization (Krueger 1995).

\section{A protracted process of transformation}

Turkey launched a thorough market reform program in 1980, earlier than many of its counterparts in the developing world. It became the poster child of international financial institutions (IFIs) until the late 1980s for its pioneering role and the speed of the reform process. Then, it took on a lethargic mood in the 1990s succumbing into a treacherously-long "lost decade" marked with vicious cycles, resulting in major crises in 1994 and 2000-2001, the last being the most severe in Turkish history. ${ }^{4}$ Then, it launched another major reform process, this time with a greater effort to institutionalize, as following sections will explicate.

Since the 1980s, Turkish economy has been transformed from a nearly-closed economy where rate of openness was $9.1 \%$ in 1979 ruled by an interventionist state to a hybrid market economy with increased exposure to global commodity and capital markets where rate of openness increased to $52.2 \%$ in 2008 , yet not entirely departing some of the characteristics of the previous era. ${ }^{5}$ Both the institutional legacies and the size of the anti-reform coalition made the process a rather protracted one marked by major zigzagging where discretionary policy-making, populism and de-institutionalization were central (Öniş and Şenses 2009, Ozel 2003, 2010b). As the Chart 3 shows, the level of openness in Turkey was lower than in Brazil until the 1980s, but it in increased substantially at a much higher rate since then.

Following the change in the development strategy in the 1980s, income growth began to be highly correlated with the exports growth, and such correlation increased further in the last decade. Chart 4 demonstrates Turkish economy's increasing export dependency.

In the initial phases of transitions, politicians who encountered with increasing political competition usually undermined the necessity of a solid institutional framework for reforms. They opted to proceed through bypassing the existing institutions based on a short-cut pragmatic stance by means of discretionary tools, 
Chart 3. Openness, Brazil and Turkey, 1960-2010

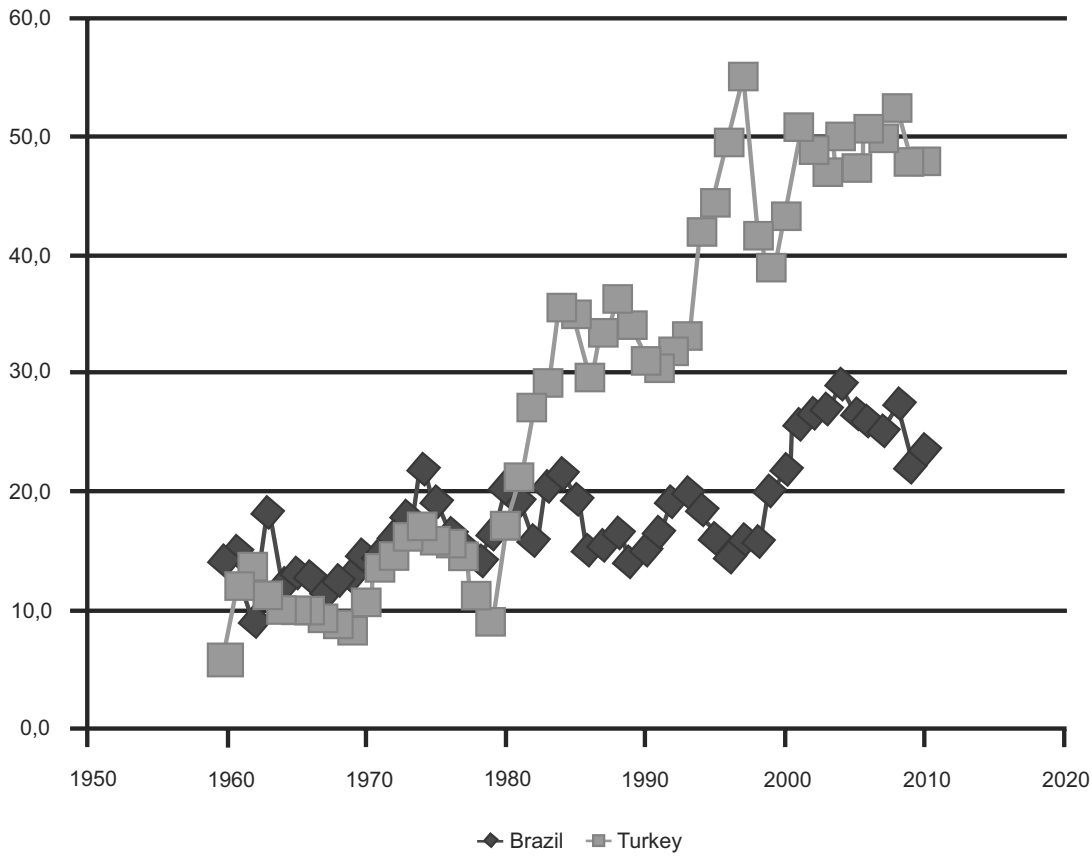

Source: World Development Indicators database, World Bank

Chart 4. Export-led growth in Turkey, 1987-2010

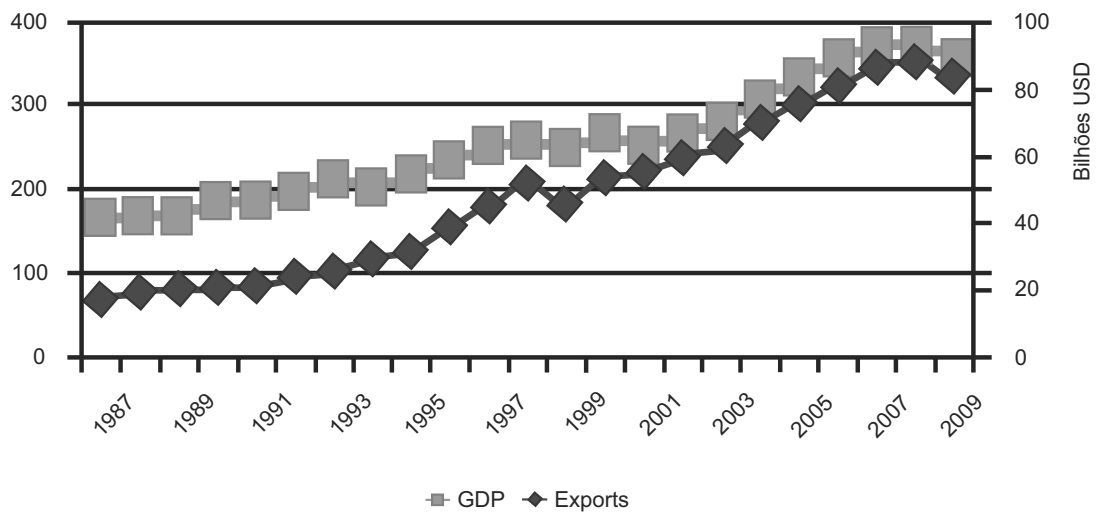

Source: Central Bank of Turkey. 
leading to liberalization accompanied by de-institutionalization (Öniş 2004, Kalaycıoğlu 1994). One of the most significant examples of undermining institutional frameworks could be observed in privatization process which was initiated and conducted in the absence of a legal framework up until the mid-1990s (Atiyas 2009, Öniş and Şenses 2009).

\section{$1^{\text {st }}$ phase of market transitions: $1980-2000$}

The milestone of Turkish transformations was the reform program popularly known as "January 24 decisions," a comprehensive policy bundle entailing a wide range of liberalization in the areas of financial markets; foreign trade; capital markets; and privatization of public enterprises. However, the realization of these ambitious goals not only took a long time (some of which, like privatization, have not been completed as of now), but their application diverged from initial orthodox rhetoric, since it has ended up with a mish-mash of government intervention and populism. Although the 1980 package had announced the opening of the Turkish economy to the world, the implementation of trade liberalization in its initial phases emphasized export promotion rather than overall liberalization, turning de jure Washington Consensus into a de facto mercantilism in the initial phases of liberalization. Import liberalization gained a new momentum with the initiation of the Customs Union process in 1989. Albeit launched in 1985, privatization mostly stalled until the 2000s.

Resonating Latin America in the 1980s, 1990s are usually referred to as "the lost decade" in Turkey since macroeconomic indicators worsened, privatization stalled, stabilization efforts stumbled, as expansionary fiscal policies shaped economic policymaking. Credibility of governments' policies diminished in this period and populism marked the policymaking processes. The critical changes were launching the Customs Union agreement with the EU (1995) and the capital account liberalization (1989) in the midst of severe instabilities. Usually referred to as "premature" opening (Rodrik 1991), capital account liberalization enabled arbitrage-seeking short-term capital inflows (hot money) and made high interest rates sticky, triggering a process between governments (borrowing through GDIs at high interest rates); commercial banks (client of GDIs and host of short-term foreign capital inflows); and individual investors (lend to commercial banks at extremely high overnight interest rates). Successive governments exacerbated a disastrous vicious cycle by increasing indebtedness and interest rates to attract "hot money" in order to finance their expansionary fiscal policies and debt. On the other side, high interest rates hindered investment because of the skyrocketed cost of credits for the real sector. The Turkish economy got into a spiral of high levels of debt, interest rates, and inflation along with a new debt crisis where domestic debt mostly replaced the foreign debt. In the lure of hot money, the Turkish economy was trapped in a vicious cycle of debt and sticky rates of interest and inflation. ${ }^{6}$ High interest rates and inflation impaired investment; public-private competition in the financial markets 
(and the former's virtual hegemony in those markets) diminished the availability of credits.? The culprit behind the disastrous spiral was not only the governments which financed deficits by further borrowing, but business also contributed by transferring its resources to the GDIs and securities, partially facilitating a "rentier-economy" while perpetuating clientelistic mechanisms (Köse and Yeldan 1998). Such spiral gave rise to three major financial crises emerged in 1994, 2000 and 2001, the latest being the deepest in Turkish history.

\section{$2^{\text {nd }}$ phase of market transitions: Post-2001}

The 2000-2001 crises became an important milestone in Turkey, bringing about major institutional reforms along with macroeconomic stabilization. Political stability also followed course as the unstable short-termed coalition governments came to an end in 2002, as replaced by a strong one party-government which has recently started its third term. In accordance with the "post-Washington Consensus" and emerging belief in good governance, Turkish economy has gone through a process of institutionbuilding and reforming mostly fostered by international and regional actors, such as the IMF and the EU, usually referred to as "double anchors" whose conditionalities played important roles in policy changes and institutional reforms (Öniş and Şenses 2009). Turkey's official candidacy to the EU in 1999 and the launching of accession negotiations in 2005 were critical turning points, pushing Turkey to undertake reforms to fulfill the Helsinki criteria. Geopolitical considerations also mattered in increased funding for the recovery from the crisis which almost coincided with 9/11 attacks in the U.S., giving rise to a restructuring of U.S.' foreign policy with increased importance of Turkey, hence, U.S.' endorsement for the IMF funds.

Significant institutional and policy changes have been introduced in the post-2001 governance including the rise of a regulatory state (notwithstanding its adjectives); social policy reforms; and fiscal discipline. As regulatory governance was considered central in this recent transformation, regulatory frameworks were created and nine independent regulatory agencies were established through a so-called "regulatory inflation" in a relatively short time span (Ozel and Atiyas 2011). ${ }^{8}$ Regulatory frameworks in some policy areas, including finance and competition, have converged with international standards. However, the executive discretion continued to prevail in regulated markets as well, marked by high degree of political intervention in ideallyand allegedly -independent regulatory agencies which regulate the markets. Hence, the Turkish regulatory state mostly espouses an illiberal character through prevalent use of political control (Ozel 2012 and forthoming).

Soundness of Turkish banking in the context of the current crisis is brought about by such strong frameworks monitored by the Banking Regulation and Supervision Agency. The independence of the Central Bank was also significant, playing a central role in macroeconomic stability attained after decades (Alper and Hatipoğlu 2009). 
Fiscal discipline has been a prominent characteristic of this recent phase, not only in terms of rule-setting but also rule-implementing. Commitment to limit public debt through fiscal prudence is displayed by the enactment of successive fiscal responsibility laws. The often acknowledged resilience of the Turkish economy in the context of the current financial crisis is mainly provided by regulatory framework and fiscal discipline which worked as filters against the crisis.

Nonetheless, a major paradox prevails here: the invincible Turkish state has currently been in the process of hazarding some of the most essential institutions executing regulation which facilitated such resilience against the crisis. The rules which enhanced the Turkish ME's capacity to resist against the crisis have been established by the regulatory agencies endowed with substantial authority and independence. Although the regulatory state which mostly works through independent agencies is on the rise throughout the world, the current government in Turkey has decided to diminish (even abolish) the independence of those agencies allegedly "for the common good". Regulatory agencies were already subject to increasing levels ofmostly-de facto political intervention along with the interventions facilitated by the de jure changes regarding their independence and authority structures. But, an important juncture regarding politicizing the regulatory processes has recently taken place: a decree-law was enacted in August 2011 which put forward that "the [respective] minister has the authority over all transactions and activities of the related, attached and affiliated agencies" which, by definition, include the IRAs. ${ }^{9}$ Through this legal change, regulations as well as other transactions of the IRAs become subject to political control, giving rise to a process of de-delegation of authority by the executive, concomitant with the pattern of de-institutionalization (Ozel 2012). This shows the reluctance of the executive authority to delegate power justified by its desire to enhance its capacity to respond more flexibly to the ongoing global crisis It is yet to be seen if the governments' capacity to fight economic crises will increase by means of intervening in the regulatory processes.

Thus, major legacies of the past prevail and endanger the sustainability of newly-established institutions. Executive discretion, politicization of bureaucracy and deinstitutionalization, which marked the post-1980 transitions still prevail at the expense of endangering some of the basic institutions which enabled post-2001 recovery and resilience against the current global financial crisis (Ozel 2012). The Turkish case perfectly exemplifies the tension between the old and the new and how reforms might be impaired or sometimes invalidated by previous institutional settings and the entrenched interests in those.

In regards to governance, Turkey still suffers from weak or ineffective institutions; corruption persists; informal economy and taxation pose major problems (Öniş and Şenses 2009). Even the recent EU accession process and its strict conditionalities has not been a panacea for this, because de jure formation and existence of institutions in order to fulfill the necessary criteria does not necessarily guarantee their de facto 
operation. The discrepancies between de jure design and de facto operation of various institutions in Turkey can be easily observed regarding rule of law, regulatory quality and voice and accountability. ${ }^{10}$

Additionally, political will to undertake liberal reforms emerged brought about by the negative experiences of the crisis, but also coming to power of a new political party, the current incumbent, the Justice and Development Party (JDP), self-acclaimed "conservative democrats," who effectively combined their anti-establishment stance (particularly against the secularist civilian and military bureaucracy) with pro-market ideology, a curious mix generated by the modern Turkish history (Ozel 2012 forthcoming). JDP is considered to be the political party with highest levels of commitment to the ideals of liberal economy, state's withdrawal from the economic realm, even at higher levels than the Motherland Party, the pioneer of market reforms in Turkey (Düşkün 2009). Nevertheless, the relatively young JDP's governments also maintained patrimonialist patterns and furthered clientelistic mechanisms by means of constructing novel forms of give-and-take with their allies amongst different social groups.

Akin to the Labor Party's unprecedented rise in Brazil, JDP came to power in 2002, forming a one-party government following successive coalition governments between 1991 and 2002. JDP's commitment to reforms was more striking in its first term (2002-2007) when major institutional reforms were carried out, and stabilization was achieved. Before the global financial crisis broke out, Turkish economy was one of the fastest growing economies in Europe and the Middle East, as it grew at an average rate of $7.2 \%$ between 2002 and 2006 , when the global liquidity also prepared a suitable ground. In fact, the global liquidity boom helped not just Turkey since many countries, including Brazil grew at remarkable rates. ${ }^{11}$ The Chart 5 below displays the changes in GDP growth rates in Turkey and Brazil since 1990, indicating that the fluctuations in the Turkish economy have been much more drastic than in Brazil, as negative growth rates prevailed at the times of the crises in 1994, 2000-2001 and 2008.

An important issue to underline here is that the "success" of the JDP in terms of recovery from the severe crisis (which caused a drastic downturn in Turkish economy, signified by 6-7\% annual drop in GDP) was mainly based on the programs (particularly the "Strong Economy Program") designed and implemented by the previous coalition government. Yet, presence of a strong base for recovery cannot undermine the commitment, and resulting performance of the JDP governments for furthering reforms, and stabilizing the economy. Some of the indicators of stabilization were the decline in inflation rate (from $35 \%$ in 2002 to $6.5 \%$ in 2009)..$^{12}$ Since 2002, FDI flows increased to an unprecedented level, partially facilitated by effective privatization of state owned assets-as explained in the respective section. The growth spurt carried out in the first half of the 2000s was partially a recovery from the crisis, and it was facilitated by both sound macroeconomic policies and a favorable environment in global markets. 


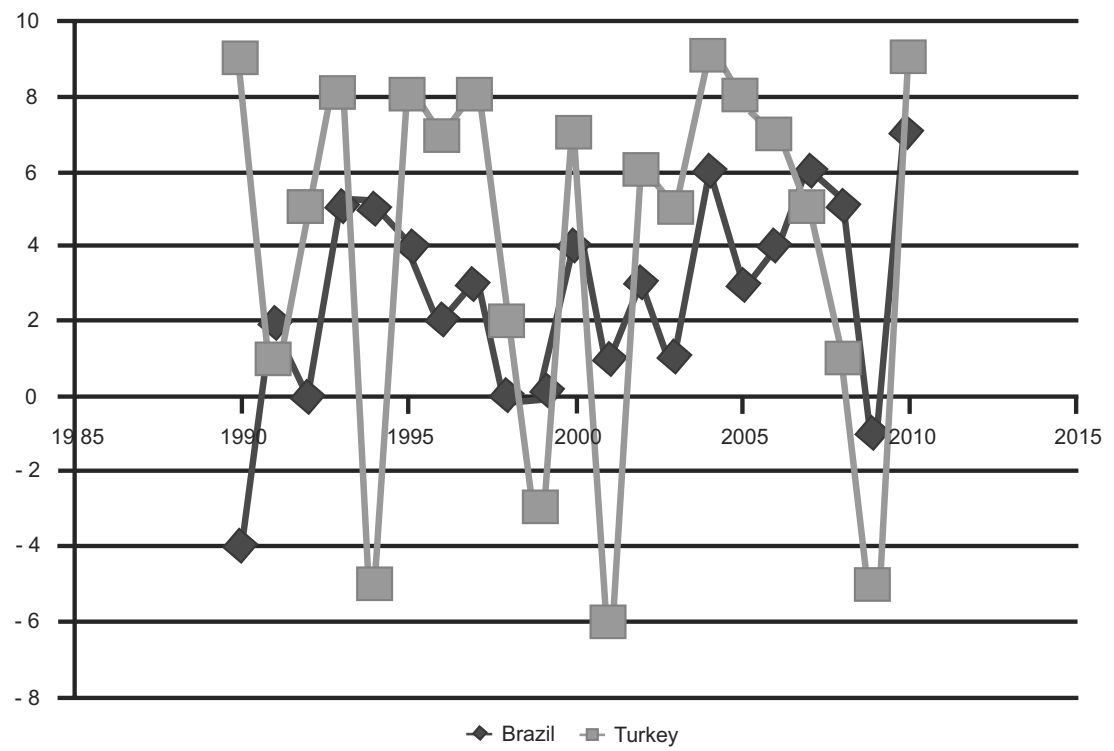

Source: World Development Indicators database, World Bank

Nevertheless, the global financial crisis which emerged in 2007 halted this upward trend, when the Turkish economy was far from ready to take such a major challenge. It encountered the crisis in a relatively weak position with a high current account deficit, low savings rate, and resulting dependency on short-term capital inflows. In the presence of such obstacles along with high unemployment and institutional flaws particularly with respect to governance, macroeconomic indicators began to worsen in the second term of the JDP government (2007-2011). A persistent-and the most important-problem facing the Turkish economy is the current account deficit that arose from $\$ 22.1$ billion in 2005 up to $\$ 47.7$ billion in 2010, constituting $6.6 \%$ of the GDP. ${ }^{13}$ Current account deficit increases rapidly during fast growth episodes, and falls when the economy slows down, and the deficit has prevailed since the mid-1990s, except for the year 2001. Expectedly, the alarming outcome of such expanding current account deficit is the dependence on short-term capital inflows which introduces considerable volatility to the Turkish market. Chart 6 below displays the recent increase in current account deficit.

Another major issue in Turkish economy is the income gap--albeit at a lower level compared to that in Brazil. Although the Gini coefficient based on income, a commonlyused indicator of the income gap, has declined gradually since the 1990s (from 0.49 in 1994 to 0.44 in 2002 and 0.40 in 2004), the coefficient based on consumption has 
Chart 6. Current Account Deficit in Turkey

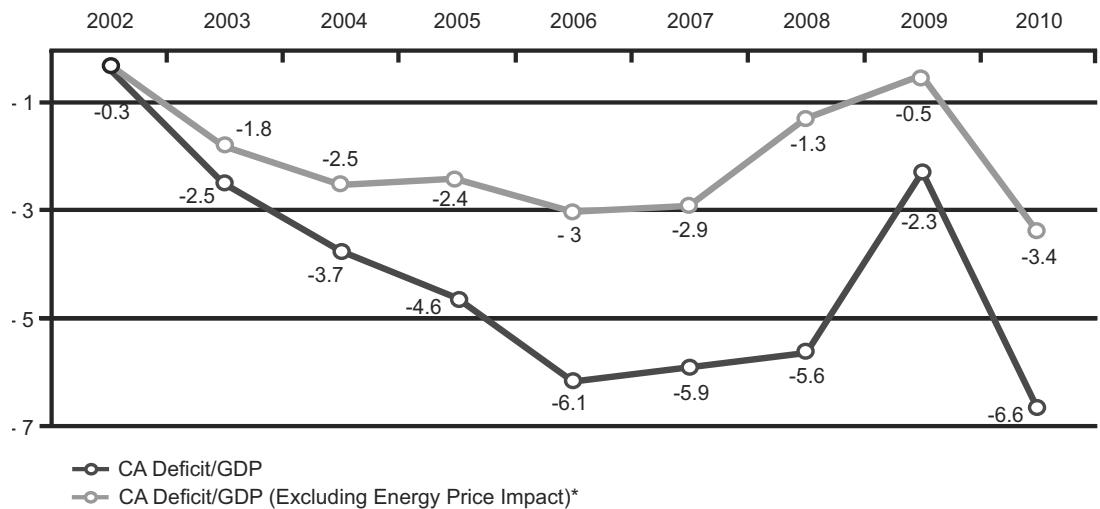

Source: Central Bank of Turkey.

slightly increased (from 0.42 in 1994 to 0.43 in 2002). The economic crises in 1994 and 2000-2001 are considered to have caused the decline in the Gini coefficient, since particularly the latest crisis hit higher income percentile significantly. ${ }^{14}$ Nevertheless, cross-regional income gap within Turkey is still striking and growing further.

\section{Privatization: a thorny road}

Privatization process was launched in Turkey much earlier than in most other emerging countries, but its progression has lagged behind those countries (Ercan and Öniş 2001). For two decades after its launching in 1985, the cumulative privatization revenue only reached $\$ 9.4$ billion, while it was $\$ 5.7$ between 1985 and 1999 . The average annual privatization revenue was about $\$ 500-600$ million in the 1990 s and rose up to $\$ 8$ billion in 2005-2006 (Atiyas 2009: 1, 4). Thus, despite its relatively long history, privatization only gained momentum within the last decade, particularly after 2004. Additionally, privatization has moved to infrastructure industries such as telecommunications and electricity, though the divestiture in some segments of the latter is still problematic. Since the year 2000 , the cumulative divestiture totalled $\$ 37.3$ billion, while the overall total since 1985 is being $\$ 41.9$ billion. ${ }^{15}$ Some of the giant SOEs have been privatized since 2004 including Turkish Airlines, Turkish Telecom, Tüpraş (refinery), Erdemir (steel), through the privatization of the last three had been launched in the early 1990s, but they were all subject to legal obstacles (and struggles later) and strong opposition as they were deemed highly "strategic."

State-owned enterprises had a major share in Turkish economy, particularly in manufacturing brought about by the state-led development and the principle of etatism 
adopted in the 1930s. Between 1950-1960, the SOEs already constituted about $60 \%$ of total value added in manufacturing, and this ratio went down to $40 \%$ at the onset of the launching of privatization in 1985, and then further declined to $18.5 \%$ in $2000 .{ }^{16}$ There are still SOEs (some to be privatized) and prominent public banks which constitute about $35 \%$ of all actives in the Turkish banking sector (32\% in Brazil, 35.5\% in Russia). ${ }^{17}$

One of the major factors behind such protracted implementation was the absence of a legal framework for privatization in Turkey, as divestiture of SOEs was deemed as a violation against the constitution and the existing legal framework lacked coherence as it was complex and disorganized, while the agencies and the rules they were subject to changed constantly up until the late 1990s (Atiyas 2009: 2-4). In line with the legacy of bypassing existing institutions rather than reforming then, the successive governments since the 1980s opted for shortcut solutions to circumvent the laws rather than creating a solid legal framework for the privatization process. As the previous sections also emphasized, introducing major reforms in the absence of establishing necessary institutional changes was a characteristic feature of the first phases of Turkish market transition process.

The argument that "privatization was un-constitutional" was broadly used by the anti-privatization coalition, usually led by the opposition parties and statist intellectuals. Interestingly enough, all parties from different points in the left-right pendulum attacked privatization whenever they were in opposition, but owned and promoted it whenever they came to power, indicating the lack of demarcations between economic policies across political parties throughout the 1980s and 1990s (Düşkün 2009). Starting from the late 1980s, several privatization attempts were brought to the Constitutional Court of Turkey by the opposition parties and the Court invalidated those cases which had been launched by means of several decreelaws issued to bypass the legal constraints in a pragmatic fashion. A legal framework which thwarted such unconstitutionality of privatization was established in 1994 by the Privatization Law, No. 4046, setting the principles, procedures, authorised agencies and other issues regarding privatization. Following a series of revisions, the legal framework was finalized in 1997, and began to contain established rules about international arbitration as late as 1999. Later in 2003, an amendment was issued to accelerate privatization processes by the Law No. 4971, entitled 'Law Regarding Making Amendments in Some Laws and in the Decrees with The Force of Law Dealing with Establishment and Duties of the General Directorate Turkish National Lottery'.

In addition to the legal constraints, the small size of the pro-privatization coalition and accordingly the lack/ inadequacy of a political will to privatize also played a role in the protracted nature of the process (Atiyas 2009, Ökten 2006). The broad coalition against privatization was not only consisted of workers of the SOEs, but also included bureaucrats (not only of the SOEs), public employees, certain segments of the intelligentsia as well as the general public (Ercan and Öniş 2001). In this process of opposition, the internalized statist ideology was effectively used by the opposition 
parties for whom the absence of a legal framework provided a large legitimization space. The privatization in strategic sectors proved particularly difficult, as has been observed in the case of Turkish Telecom whose privatization had been initiated in 1994, and finalized in 2005.

The JDP has been the most committed incumbent regarding privatization, which can be assessed based on its party programs compared to the others' since the early 1980s (Düşkün 2009). The widespread skepticism toward privatization and particularly about divestiture to foreign capital, which have been owned by all parties across different ideological stances, has not existed in the case of the JDP whose governments have played an important role in changing the prevalent discourse against privatization and foreign capital inflows, as the section below demonstrates. However, strikingly different outcomes of privatization process in the 2000 s can also be explained by strong incentives that the JDP governments had to privatize, given the rigid fiscal adjustment programmes in the context of the post-2001 conditionalities imposed by the creditors (Atiyas, 2009).

Although the privatization process has not been completed and there are still 25 companies in the privatization portfolio besides those not included, the state withdrew entirely from some sectors such as cement, dairy production, forest products, and petroleum distribution, while more than $50 \%$ of its shares have been privatized in sectors like tourism, iron and steel, textile and sea freight. Interestingly, only a few of the public banks have been privatized, whereas some of the largest banks in Turkey are still public. Chart 7 below demonstrates the progression of the privatization process since 1985.

Chart 7. Privatization in Turkey, 1985-2011.

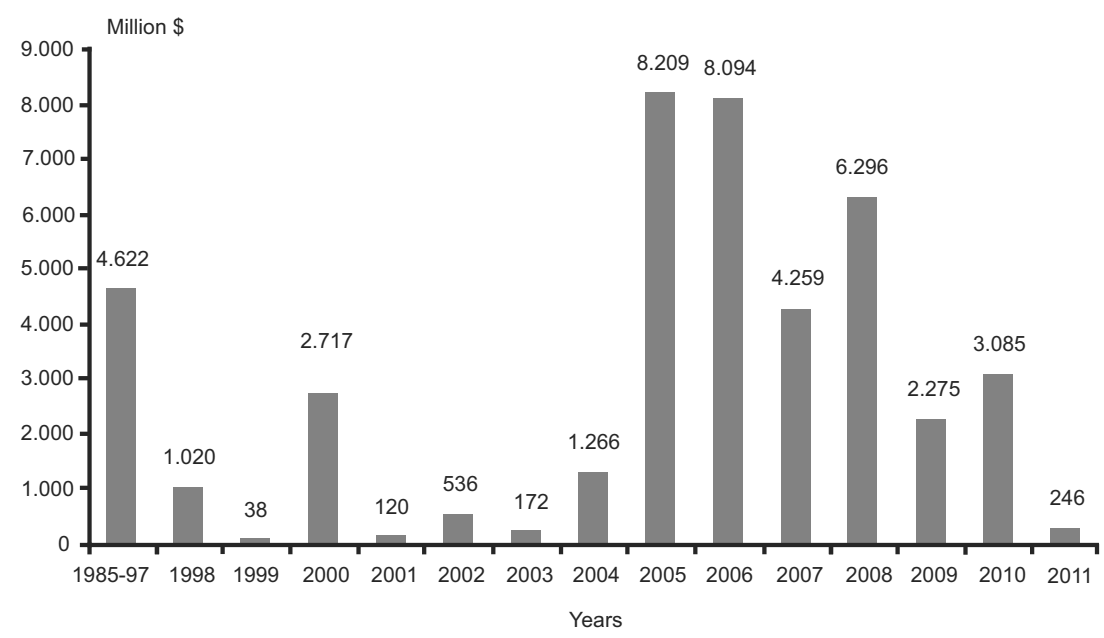

Source: Privatization Administration, The Prime Ministry of Turkey 


\section{Foreign direct Investment: A novel development in Turkish market}

One of the most remarkable changes in Turkish economy is the increase in FDI inflows since the 2000 s partially tied to the recent surge in privatization process. Turkey went through an extremely sluggish path regarding the FDI inflows and it was identified as a country with low FDI attractiveness throughout the 1990s. It received drastically lower inflows compared to BRICs and other emerging countries' averages. For instance, in 1990, both Turkey (684 million USD) and Brazil (989 million USD) received less than a million USD FDI inflows, but in 2000, Brazil (33 billion USD) received 33 times as much as the FDI inflows into Turkey ( 1 billion USD). ${ }^{18}$ Nevertheless, there has been a remarkable upward trend in FDI inflows into Turkish market: they went up to $\$ 10$ billion in 2005, catching up with Brazil in 2006 and reaching $\$ 22$ billion in $2007 .{ }^{19}$ In line with the global trend, FDI inflows showed a substantial decline after the emergence of the global financial crisis in 2008, dropping from 18 billion dollars in 2008 to 9 billion dollars in 2010. At this point, Brazil's FDI performance is remarkable: Although the inflows dropped from 45 billion USD to 25 billion USD between 2008 and 2009 , they recovered to 48 billion USD in 2010. FDI outflows from Turkey also followed a similar trend: they declined from 3 billion dollars in 2008 to 2 billion dollars in 2009. ${ }^{20}$ Chart 8 below shows the changes in FDI inflows in Turkey and Brazil since the 1980s.

Chart 8. FDI Inflows into Turkey and Brazil, 1980-2010

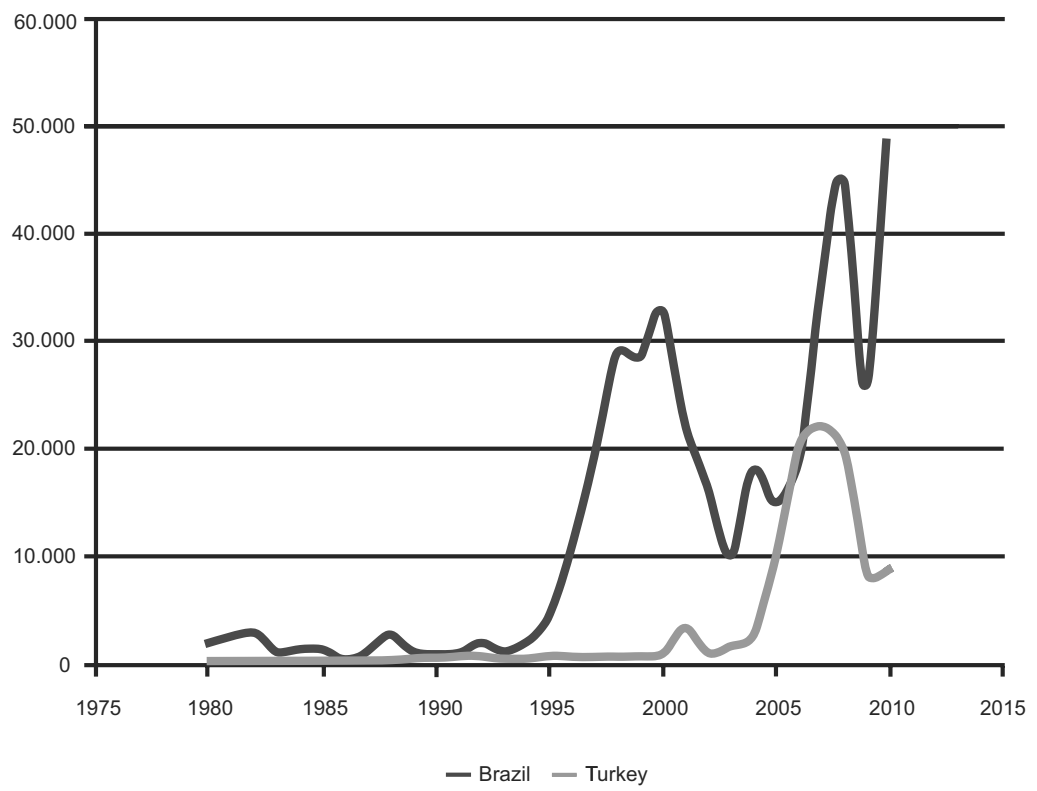

Source: World Investment Report, 2011, UNCTAD-WIR 
A significant cause of such discrepancy in the 1990s was the economic and political instabilities in Turkey including high inflation, high interest rates and high public debt along with unstable political environment in which nine different governments came to power. In a business environment where the state crowded out the market by becoming the rival of the corporate sector in the financial markets, foreign capital hesitated to invest in Turkey. In the existence of such severe instabilities, a protracted process of start-stop reforms marked by weak commitments of the incumbents and skepticism towards foreign capital fed by populist policy-making curtailed potential FDI inflows to the Turkish market. An insolvent and indebted state, chronic inflation, credit difficulties, insider credit transactions accumulated and triggered the 2001 crisis in Turkey, which provided another backlash against the FDI inflows. Nonetheless, fast recovery after the 2001 crisis led to a spurt of FDI inflows. Recent improvements in public finances which helped economic stabilization; the EU accession process and recent improvements in legal, administrative and regulatory framework (including the establishment of the Advisory Council, abolishing Treasury's authority in providing permits, easing the process of starting business); and the privatization programme facilitated positive signals to the investors, prompting FDI inflows.

\section{Social Policy}

Social policy and its central institutions went through considerable reforms in the last decade concomitant with the reforms in other dimensions fostered by several sources, including the EU. In the path of the EU accession process, Turkey has had to adopt and implement the acquis of the European Community with respect to several areas in social policy, labor market regulations and employment policies (Adaman et al. 2007). Recent institutional reforms altered the institutional framework which had served since the 1950s. It, in fact, was a highly fragmented framework in the existence of three major public institutions: the Public Employees' Retirement Fund (ES, founded in 1950, covering civil servants including the civilian and military bureaucracy); Social Insurance Institution (SSK, established in 1964 covering blue collar workers), and the Social Insurance Institution for the Self-Employed (Bagkur, established in 1971 covering the artisans, farmers, voluntarily insured in agriculture and homemakers as well as the self-employed) all entailing different conditions for eligibility and benefits. This fragmented framework generated significant distributional consequences along with fairness issues amongst the contributors (Adaman et al. 2007: 28).

In 2006, these individual institutions were merged into a new umbrella agency, Social Security Institution (SGK), which was established by the Law No. 5502, based on the goal of maintaining a financially sustainable retirement, easier access to health care and harmonizing eligibility conditions and benefits across beneficiaries of the previous institutions. In addition, health and social assistance have been separated from retirement benefits. Some of the articles of the reform package were 
first invalidated by the Constitutional Court and later the law was enacted in 2008 (Uşan 2009). A parametric reform was introduced in order to decrease substantial deficits of the social security system and a healthcare reform was carried out to offer universal coverage, currently covering more than $90 \%$ of the population. ${ }^{21}$ A program called "Transformation in Health" was introduced in 2003 based on a referral system and a health insurance fund integrating functions and collections within the former agencies, strengthening the role of the Ministry of Health in provision of health care. In the reform process, the share of social expenditures (education, health and social protection combined) in the GDP rose from 15.1\% to 19\% between 1999 and 2006, while the budgetary transfer to the Social Security Institution increased from $2.81 \%$ of the GDP (combined transfers to previous three institutions) in 2000 to $5.56 \%$ in $2009 .{ }^{22}$ Another important component of recent reforms has been the detachment of social assistance from social insurance.

The populist policy making of the 1990s had caused major inefficiencies in the social security system, the most important of which being the change allowing employees to collect retirement benefits as early as ages 38 and 43 (for women and men respectively), after paying contributions for 20 years. Thus, this made the median retirement age in Turkey much lower than those in the OECD and other countries. The Social Security Act of 1999 (Law No. 4447) first introduced a new scheme to increase retirement age to 58 and 60 (for women and men respectively) following a transition period of 20 years (amended in 2002) and the 2007 Law (\#5502) has complemented it by gradually increasing the retirement age further to 65 by 2036 for both men and women (Adaman et al. 2007).

Table 1- Employment Status/ Registration With A Social Security Institution

\begin{tabular}{|c|c|c|c|c|c|c|}
\hline & \multicolumn{2}{|r|}{$1990^{(1)}$} & \multicolumn{2}{|r|}{2001} & \multicolumn{2}{|c|}{2010} \\
\hline & $\begin{array}{c}\text { Total } \\
(1000)\end{array}$ & $\begin{array}{c}\text { Unregistered } \\
\text { (\%) }\end{array}$ & $\begin{array}{c}\text { Total } \\
(1000)\end{array}$ & $\begin{array}{l}\text { Unregistered } \\
(\%)\end{array}$ & $\begin{array}{c}\text { Total } \\
(1000)\end{array}$ & $\begin{array}{c}\text { Unregistered } \\
\text { (\%) }\end{array}$ \\
\hline Overall & 19.030 & 55,1 & 21.524 & 52,9 & 22.594 & 43,2 \\
\hline $\begin{array}{l}\text { Salary/wage } \\
\text { earner }\end{array}$ & 6.421 & 17,3 & 8.385 & 15,7 & \multirow{2}{*}{13.762} & \multirow[t]{2}{*}{25,7} \\
\hline Daily-waged & 998 & 75,4 & 1.771 & 83,7 & & \\
\hline Employer & 961 & - & 1.139 & 16,2 & 1.202 & 25 \\
\hline Self-employed & 5.077 & 64,3 & 5.365 & 68 & 4.548 & 68 \\
\hline $\begin{array}{l}\text { Non-paid family } \\
\text { worker }\end{array}$ & 5.573 & 96,2 & 4.865 & 97,7 & 3.083 & 92,2 \\
\hline Agricultural & 8.735 & 90,1 & 8.089 & 91,8 & 5.683 & 85,5 \\
\hline Salary/wage earner & 129 & 57,4 & 50 & 36 & \multirow{2}{*}{527} & \multirow{2}{*}{86,3} \\
\hline Daily-waged & 297 & 92,2 & 306 & 96,4 & & \\
\hline
\end{tabular}


Table 1 (cont.) - Employment Status/ Registration With A Social Security

\begin{tabular}{|c|c|c|c|c|c|c|}
\hline & \multicolumn{2}{|r|}{$1990^{(1)}$} & \multicolumn{2}{|r|}{2001} & \multicolumn{2}{|c|}{2010} \\
\hline & $\begin{array}{c}\text { Total } \\
(1000)\end{array}$ & $\begin{array}{c}\text { Unregistered } \\
(\%)\end{array}$ & $\begin{array}{l}\text { Total } \\
(1000)\end{array}$ & $\begin{array}{c}\text { Unregistered } \\
(\%)\end{array}$ & $\begin{array}{l}\text { Total } \\
(1000)\end{array}$ & $\begin{array}{c}\text { Unregistered } \\
\text { (\%) }\end{array}$ \\
\hline Employer & 70 & - & 70 & 64,3 & 95 & 63,2 \\
\hline Self-employed & 3.124 & 79,4 & 3.332 & 82,5 & 2.418 & 76 \\
\hline $\begin{array}{l}\text { Non-paid family } \\
\text { worker }\end{array}$ & 5.115 & 98,5 & 4.331 & 99,7 & 2.643 & 94,7 \\
\hline Non-agricultural & 10.295 & 25,5 & 13.436 & 29,5 & 16.911 & 29,1 \\
\hline Salary/wage earner & 6.292 & 16,5 & 8.335 & 15,6 & \multirow{2}{*}{13.235} & \multirow{2}{*}{23,3} \\
\hline Daily-waged & 700 & 68,4 & 1.465 & 81 & & \\
\hline Employer & 891 & - & 1.069 & 13 & 1.108 & 21,8 \\
\hline Self-employed & 1.954 & 40,2 & 2.033 & 44,1 & 2.129 & 59 \\
\hline $\begin{array}{l}\text { Non-paid family } \\
\text { worker }\end{array}$ & 458 & 46,9 & 534 & 81,8 & 440 & 76,8 \\
\hline
\end{tabular}

Source: Social Security Institution

Despite these changes in the direction of expanding social security expenses and schemes, the presence of a large informal sector hazards the availability of social security for a considerable portion of the population. The eligibility in most programs is based on formal employment, thus, a substantial portion of the workforce does not even have access to those except for health. Hence, social networks (including those based on religious orders, movements, etc.), family and more extended kinship ties provide a broad range of assistance albeit their shrinking state in time (Buğra and Keyder 2003).

\section{The state vis-ò-vis capital and labor}

\section{State-capital relations and corporate governance}

State-capital relations and corporate governance practices in Turkey entail most of the characteristics of hierarchical, statist and patrimonial market economies. Indeed, Turkey displays striking similarities with its Latin American counterparts including that of Brazil in this dimension as highly diversified large conglomerates--mostly controlled by families, like the grupos, dominate the Turkish market economy as a central characteristic of hierarchical MEs (Schneider 2009). Commonly referred to as "groups", these concentrated conglomerates have access to multi-sectoral investment and inter-firm proprietary structures and they are the very products of state-led capitalism which explicitly encouraged conglomerates to specialize in distinct fields, partitioning the production of consumer products, and acquiring major incentives towards 
monopolization. Additionally, varying forms of state interventionism in the market persist as an important feature of statism; and clientelistic patterns between the state actors and businesses continue, signifying the presence of patrimonialism (Becker 2011).

Although a history of a state-nurtured business in Turkey is similar to those in other late-developers including Brazil, Turkish state-led development-coinciding with nation-building - began after the business actors of the late Ottoman Empire were all but eliminated. Business elements, who had overwhelmingly been constituted of non-Muslim elements, were mostly eliminated in the dissolution of the empire at the beginning of the twentieth century through wars; the massacre and deportation of the Armenian community; and the convention of compulsory population exchange between Greece and Turkey in 1923 (Aktar 2006, Gocek 1996). State leaders were eager to replace them with a so-called 'national bourgeoisie,' which had to be "created" from scratch (Keyder 1987). This newly-created business community's dependence on the domestic market exacerbated by a law ruling out the "exit option:" The law on Protecting the Value of the Turkish Lira which restricting capital outflows until 1983.

For a business sector that emerged under the auspices of an interventionist state was highly dependent on it, the ISI regime and its adjoining arrangements (overall an "ISI pact") were considerably lucrative for several decades. The state's protectionist trade regime; subsidized large population with an inflated purchasing power; a repressed financial system with negative real interest rates particularly favoured big business and created diverse tools for generation and distribution of rents (Krueger 1974, Ozel forthcoming). This implicit pact, which ruled in most countries with ISI regimes, had another component in the Turkish case: secularism. The alliance between big business and the state establishment (including the military) throughout the state-led development was based on staunch support for secularism, which remained unchallenged until the rise of conservative parties with roots in political Islam and the rise of religiously conservative businesses challenging strict secularist practices in the 1990s. Commonly referred to as "Anatolian tigers" based on their eager export drive, these medium-sized enterprises formed a new alliance with pro-Islamist parties, carrying the ruling JDP to power (Ozel 2010a).

Despite the withdrawal of the state from the economy since the 1980s, particularistic clientele ties with the firms still prevail in different forms (Onis 1994, Ozel 2003). Recently, there has been a new layer in such ties that business actors who share a common religious identity (individuals and organizations alike) with the incumbent JDP might have better access to wide range of resources (Ozel 2012-forthcoming).

Although processes of market opening were expected to change dominance of conglomerates, considered as the very outcomes of the ISI phase, the empirical reality has proved this expectation wrong. Adjustment capability of conglomerates to market opening was facilitated by their shifting resources across sectors (Ozel forthcoming). However, such resilience has not necessarily thwarted increasing competition in the Turkish market particularly generated by tigers some of which have recently become 
giant conglomerates, benefiting from a wide range of selective incentives provided by the successive governments that aligned with these newly emerging businesses based on various affinities most important of which being the religious identity (Ozel 2010a). Hence, increased competition has certainly added new players into the market, but has not transformed corporate governance structures.

\section{Insider system in corporate governance}

Turkish corporate governance entails characteristics of the "insider system" such as few listed companies, large number of substantial share stakes and large intercorporate shareholdings, concentrated, mostly-family based ownership and pyramidal structure (Yurtoğlu 2000, Ararat and Uğur 2003). Pyramidal ownership structure, family control, diversification, high levels of concentration and block-holding as well as limited investment in research \& development and labor training prevail in the Turkish corporate governance practices, akin to hierarchical market economy structures in most Latin American countries including Brazil (Schneider 2009). The concentration level is very high, as the average percentage of shares held by the largest shareholder is $45 \%$ in the 100 largest traded companies in Turkey, while $28 \%$ have one shareholder with an ownership stake of at least $50 \%$ and the largest five shareholders hold $64.5 \%$ on average (Demirag and Serter 2003: 43). Families tend to be the ultimate owners in Turkish companies, since they control 68 of the top 94 traded companies, and 37 of those 68 companies are controlled through pyramids. The pyramidal structure has been fostered through incentives such as tax advantages provided for holding companies (avoiding double taxation in multiple firms-abolished as late as 1986) and transfer pricing mechanisms. Still in line with the Latin American experience, Turkish capital market used to be marked by significant problems including low levels of capital formation and liquidity, high volatility and high cost of capital, as well as the problems related to legal and regulatory framework.

Turkish corporate governance practices are subject to challenges including difficulties regarding enforcement of law and regulations, minority shareholders and creditors' rights; uncertainties arising from legal and regulatory frameworks and dismantling privileged oligopolistic coalitions that operate as corporate insiders (Ararat and Uğur 2003). The state's heavy involvement in the market for a long time led to the emergence of various rents but also private risks, which then generated pressures on the state actors to compensate such risks (Ararat and Uğur, 2003: 64).

\section{Turkish labor: squeezed between the State and capital}

State-labor relations in Turkey constitute another dimension which makes Turkish market economy fit into a hybrid form between statist, patrimonial and hierarchical, brought about by limited worker rights and the state's control over the unions. In 
fact, as a common strategy since the 1980s, governments in most emerging countries have attempted to diminish the political potency of labor unions in the process of market transitions, giving rise to different patterns of change in the state's relations with organized labor. While the trend has been toward more fragmentation and decentralization, it has been toward more centralization and concentration in the Turkish case where the state's strategy can be characterized by "unite and restrain" (Kuş and Ozel 2010). The labor movement which had been strong, but fragmented and highly politicized before 1980, was, first, annihilated by the military coup in 1980, and it later revitalized in the late 1980s but has never recuperated its power in the 1970s. Now, not only the unionization rate is much smaller ( $10 \%$ overall public and private included, though the figure often announced by the state reaches up to $68 \%{ }^{23}$ ), but also severe limits on unions' activities along with widespread repression imposed both by the state and the capital keep the unions weak. Between 1979 and 2010, the number of labor unions in Turkey dropped from 800 to 100 and currently there are 3 labor confederations. ${ }^{24}$ The Turkish state created a more centralized union movement with fewer players to enhance its control while breaking the power of large unions and de-politicizing the union movement.

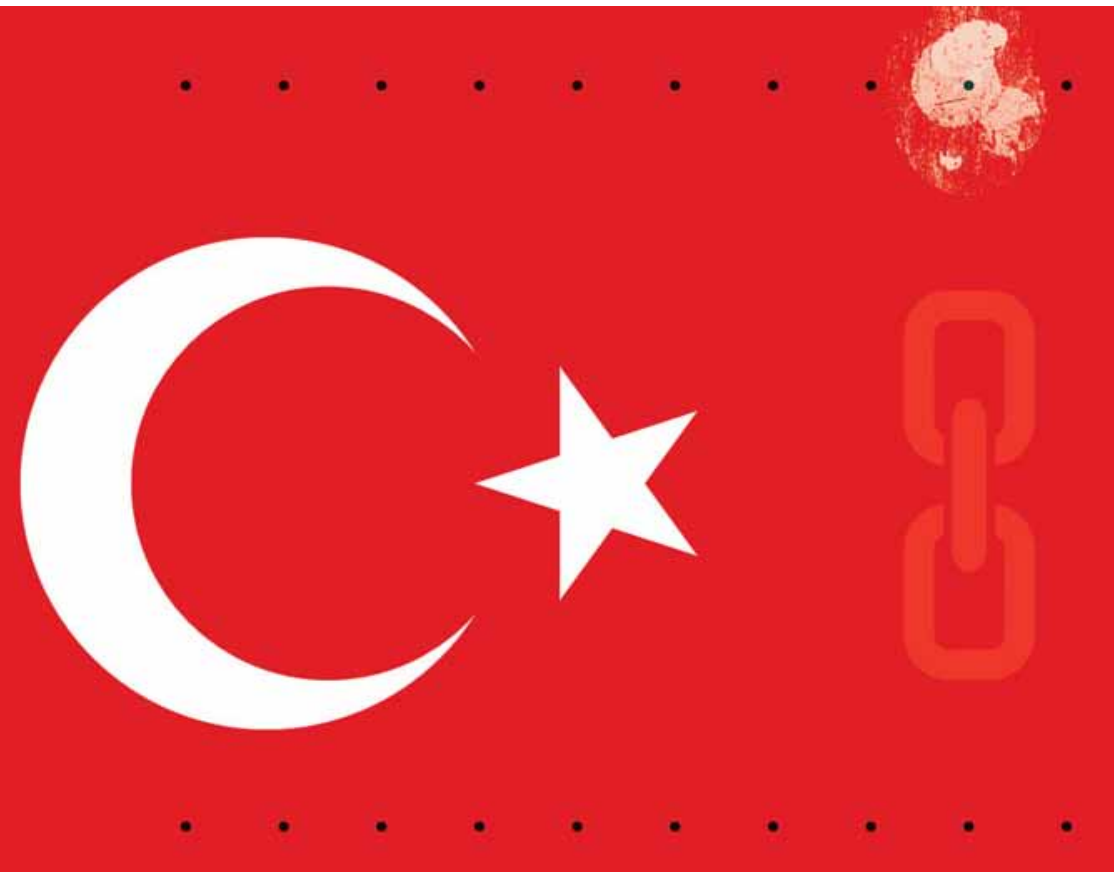


Legacies of authoritarianism in state's relationship with labor still abound. Despite the transition to (semi) democracy in 1983, the 1982 Constitution and the subsequent legal changes on the union organization, collective bargaining, strikes and lockouts mostly institutionalized the state control over the unions. Thus, the 1982 Constitution took away most of the labor rights which had been granted by the 1961 Constitution, resulting in labor's becoming a powerful actor in Turkish politics in the 1960s and 1970s (Mello 2010).

Most of the changes enacted by the 1982 Constitution are still intact and they include rules such that, unions must have the support of at least 10 percent of union membership within that industry as well as the $50 \%$ at a particular workplace in order to represent workers at a given facility. Political strikes, work slowdowns and picketing are prohibited and those who strike illegally may be subject to loss of their financial claims (including pension, or even their jobs) or imprisonment (Önder 1999).

Despite increasing state control, unions began to take on a political tone starting from the 1990s. The three confederations, namely, Türk-Iş, DISK and Hak-iş, and independent unions are in rivalry with one another. Most interesting among these actors is Hak-iş, a confederation representing a form of unionism based on nationalist and religious values and considering the conflict between labor and capital as artificial, and, instead emphasizing the commonality of employer and employee interests on the basis of Muslim brotherhood (Duran and Yildirim 2005: 231). With its 550 thousand members, Hak-iş has been in a close alliance with the successive JDP governments since 2002. ${ }^{25}$

Cooptation of the union leaders by the state and the capital together with the lack of intra-union democracy are prominent characteristics of Turkish union movement, which exacerbated further since the 1980s. The workers' representatives are now appointed by the union administration (the only exception being the independent "lefty" unions) rather than being elected by the workers which was the practice before 1980. In this context, the link between the workers and the shop-floor is extremely weak and hierarchical structures prevail in most unions, including those represented by the allegedly "revolutionary" confederation. Hence, state-labor relations situate Turkey between the statist and hierarchical market economy categories.

\section{In lieu of Conclusion}

This article explored the ways in which Turkish political economy has evolved into a hybrid form between patrimonial and statist market economies based on hierarchical structures. It discussed the formation of an illiberal market economy marked by high level of centralization and state interventionism over market players and mechanisms. Emphasizing the coexistence of continuity and change through the transformation of the Turkish political economy, the article pointed out the tensions between the old and the new institutions as well as the interests entrenched in those. It examined 
the resistance of some of the former patterns in which the Turkish state interacted with the society, while state intervention and patronage distribution has prevailed in new forms. The article drew comparisons between Turkey and Brazil in regards to the emergence of hybrid varieties of capitalism in the context of transitions from stateled development to market opening processes. Despite considering both countries as constituting hybrid varieties, it purported that, compared to its Brazilian counterpart, Turkish market economy was further inclined toward patrimonial and statist varieties, rather than the liberal one.

Although major institutional reforms were undertaken-mostly under the aegis of international and supranational actors-during severe economic crises which functioned as external shocks, the article underlined that the effectiveness of newlyestablished institutions could be at stake in Turkey, as various actors (most important of whom being the politicians, particularly the executive) with various forms of power and discretion found the ways of undermining those institutions, spawning constant vacillations between institutionalization and de-institutionalization.

\footnotetext{
Notes

' World Development Indicators, 2011, The World Bank (http://data.worldbank.org/data-catalog/worlddevelopment-indicators)

2 See: http://databank.worldbank.org

${ }^{3}$ Initial amendments to the 1961 Constitution regarding the power of decrees were made in 1971 following the military intervention, but no significant decrees were issued until 1980. The first example of decrees in Turkish legal history is the decree issued by the 36th Article of the 1876 Constitution (Kanun-i Esasi), the first Constitution of the Ottoman Empire (Karahanoğulları 1998).

${ }^{4}$ In the 1990s, Turkey's macroeconomic (mis)management caused a spiral of extensive indebtedness, chronic inflation and sluggish growth resulting in 3 major crises in 1994, 1999 and 2001 where growth rates were $-6.1 \%,-6.1 \%$ and $-9.5 \%$ respectively. Source: www.tuik.gov.tr

World Development Indicators, World Bank (http://data.worldbank.org/data-catalog/worlddevelopment-indicators)

${ }^{6}$ As the public sector borrowing requirement (PSBR) increased, the public sector's share in the financial markets increased by means of government debt instruments (GDIs).

${ }^{7}$ Between 1989 and 2000, fixed private investment increased only 5.2\% on the average, while changes in private stock (contribution to growth) averaged $0.17 \%$ (based on 1988 prices). Source: Treasury Statistics, 1980-2003. The Undersecretariat of Treasury, General Directorate of Economic Research, Ankara: 2004, p.5.

${ }^{8}$ Currently, there are nine independent regulatory agencies (IRAs) in Turkey: Capital Markets Board (established in 1982), The Higher Board for Radio and TV (1994), Competition Authority (1994 and 1997), Banking Regulation and Supervision Agency (1999), Information and Communications Technologies Authority (2000), Energy Markets Regulatory Agency (2001), Sugar Agency (2001), Tobacco and Alcohol Market Regulatory Agency (2002), and Public Procurement Agency (2002).

${ }^{9}$ Decree No. KHK/649 http://mevzuat.dpt.gov.tr/khk/649.pdf Date of access: September 2, 2011.

${ }^{10}$ The Worldwide Governance Indicators, The World Bank Group, 2011, (Note 10) (http://info.worldbank. org/governance/wgi/index.asp)

11 See: http://databank.worldbank.org

${ }^{12}$ Central Bank of Turkey. http://www.tcmb.gov.tr/yeni/eng/ Accessed on September 21, 2011.

${ }^{13}$ Sources: Central Bank of Turkey (www.tcmb.gov.tr/yeni/eng/) and World Bank Development Indicators (http://data.worldbank.org/data-catalog/world-development-indicators) . Accessed on September 20, 2011.
} 


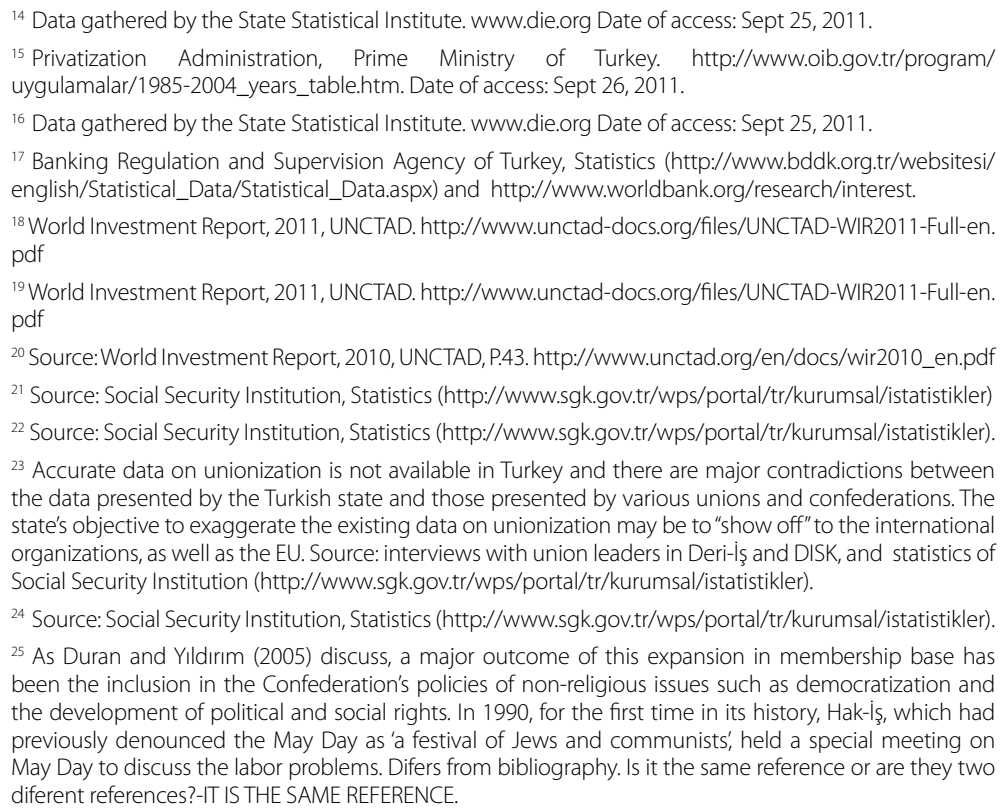

\section{References:}

ADAMAN, F., A. ÇARKOĞU and B. Şenatalar. 2007. "Corruption from the Perspective of Turkish Business, Istanbul:TESEV Publications.

AKTAR, A. (2006) Türk Milliyetçiliği, Gayrımüslimler ve Ekonomik Dönüşüm, Istanbul: Iletişim.

ALPER, E. and O, HATIPOĞLU, 2009. The Conduct of Monetary Policy in Turkey: in the pre and post-crisis period of 2001 in comparative perspective: A Case for Central Bank independence" in ÖNIŞ, Z. and F. ŞENSES, eds.,2009. Turkey and the Global Economy, Neo-liberal Restructuring and Integration in the Post-Crisis Era, London: Routledge, pp.50-72.

ARARAT, M. and M. UĞUR. 2003. “Corporate Governance in Turkey: An Overview and Some Policy Recommendations," Corporate Governance, Vol. 3, No. 1, pp.58-75.

ATIYAS, I. 2009. "Recent Privatization Experience in Turkey, A Reappraisal” in Öniş, Z. and F. Şenses, eds.,2009. Turkey and the Global Economy, Neo-liberal Restructuring and Integration in the Post-Crisis Era, London: Routledge, pp.101-122.

BANKING REGULATION AND SUPERVISION AGENCY OF TURKEY, Statistics (http://www. bddk.org.tr/websitesi/english/Statistical_Data/Statistical_Data.aspx

BECKER, U. 2011. “Comparing Institutional Change of the BRIC political economies. Theoretical considerations and first empirical results," Paper presented at the Annual SASE Meeting, Madrid, June 24, 2011.

BARKEY, Henri. 1990. The State and the Industrialization Crisis in Turkey, Boulder, San Francisco, Oxford: Westview Press.

BIRTEK, F. and B. TOPRAK (eds.). 2011. The Post-Modern Abyss and the New Politics of Islam: Assabiyah Revisited-Essays in Honor of Şerif Mardin, Istanbul: Bilgi University Press. 
BOSCHI, Renato. 2011. "Politics and Trajectory in Brazilian Capitalist Development: Recent trends", Paper presented at the International Seminar: Rethinking Capitalist Development in Emerging Countries", Rio de Janeiro, October 19-21, 2011.

BOSCHI, Renato and Carlos Henrique Santana. 2012. Development and Semi-periphery: Post-neoliberal Trajectories in South America and Central Eastern Europe, London and New York: Anthem Press.

BRESSER-PEREIRA, Luiz Carlos. 1990. "A Pragmatic Approach to State Intervention: The Brazilian Case," CEPAL Review/Revista de la CEPAL, no.41, August 1990: 45-53.

BUĞRA, Ayse and Çağlar Keyder. 2003. “New Poverty and The Changing Welfare Regime of Turkey," Ankara: UNDP.

THE CENTRAL BANK OF TURKEY, Statistics (http://www.tcmb.gov.tr/yeni/eng/)

DEMIRAĞ, Istemi and MEHMET Serter. 2003 "Ownership Patterns and Control in Turkish Listed Companies," Corporate Governance, Vol. 11, No. 1, pp. 40-52.

DURAN, Burhanettin and YILDIRIM, Engin (2005) "Islamism, Trade Unionism and Civil Society: The Case of Hak-iş Labour Confederation in Turkey", Middle Eastern Studies, 41: 2, pp. 227- 247.

DÜŞKÜN, Yeliz. 2009"Party Positions and Privatization in Turkey" unpublished Masters Project. Sabancı University, Istanbul.

ERCAN, M. and ÖNIS, Z. 2001. "Turkish Privatization: Institutions and Dilemmas" Turkish Studies, Vol. 2, No.1.

GÖCEK, Fatma M. 1996. Rise of the Bourgeoisie, Demise of Empire: Ottoman Westernization and Social Change, New York and Oxford: Oxford University Press.

GÜNEŞ-AYATA, 1994. A. "Roots and Trends of Clientelism in Turkey” in Roniger, L and Ayse Gunes-Ayata, eds. Democracy, Clientelism and Civil Society, Lynne Rienner.

HALL, P. and D. SOSKICE. 2001. "An Introduction to Varieties of Capitalism", in Hall P. and D. Soskice (eds), Varieties of Capitalism: The Institutional Foundations of Comparative Advantage (Oxford: Oxford University Press).

KALAYCIOĞLU, Ersin, 1994. “Unconventional Political Participation in Turkey and Europe: Comparative Perspectives", II Politico, anno LIX, no.3, pp.503-523

KARAHANOĞULLARI, O. (1998). "Kanun Hükmünde Kararnamenin Niteliği," Amme İdaresi Dergisi, Vol. 31, No. 2, pp.41-62.

KAZGAN, Gulten. 2004. Tanzimat'tan 21. Yuzyila Turkiye Ekonomisi, Istanbul: Bilgi Universitesi KEYDER, Caglar. 1987. State and class in Turkey: a study in capitalist development, New York:Verso, pp.141-228.

KINGSTONE, Peter. 1999. Crafting Coalitions for Reform, Penn State Press.

KOSE, A. H. and E. YELDAN. 1998. "Disa Acilma Surecinde Turkiye Ekonomisinin Dinamikleri: 1980-1997," Toplum ve Bilim, 77, pp. 45-68.

KRUEGER, Anne. 1995. "Partial Adjustment and Growth in the 1980s in Turkey," in Dornbush, Rudiger and Sebastian Edwards eds., Reform, Recovery and Growth, Latin America and Middle East, Chicago and London: University of Chicago Press.

KRUEGER, A. 1974. "The Political Economy of the Rent-Seeking Society," The American Economic Review, 64 (3): 291-303.

KUŞ, B. and I. OZEL 2010. “United We Restrain, Divided We Rule: Neoliberal Reforms and Labor Unions in Turkey and Mexico" (with Basak Kus), European Journal of Turkish Studies, 11, Fall 2010. 
LEVI-FAUR, D. (2011) 'Regulation and regulatory governance', in Levi-Faur, D. (ed.) Handbook on the Politics of Regulation, Cheltenham: Edward Elgar, 2011, pp. 3-21.

MELLO, Brian (2010) "(Re)Considering the Labor Movement in Turkey", European Journal of Turkish Studies, 11, Fall 2010

ÖKTEN, Çağla. 2006. "Privatization in Turkey, What has been achieved?" in S. Altug and A. Filiztekin (eds.), The Turkish Economy: The Real Economy, Corporate Governance and Reform, London: Routledge-Curzon, pp. 227-251.

ÖNDER, Nilgun (1999) The Political Economy of the State and Social Forces: Changing Forms of State Labour Relations in Turkey. PhD Thesis. Canada: York University.

ONIS, Ziya. 2004. "Turgut Ozal and His Economic Legacy: Turkish Neoliberalism in Critical Perspective," Middle Eastern Studies, 40: 4.

ÖNIŞ, Ziya and Fikret Şenses eds., "Turkey and the Global Economy, Neo-liberal Restructuring and Integration in the Post-Crisis Era", Routledge, 2009.

OZEL, I. 2012. "The Politics of De-delegation: Regulatory (in)dependence in Turkey," Regulation and Governance, Vol. 6, No.1, pp.119-129.

OZEL, I. 2012 forthcoming. "Is it none of their business? Business and democratization, the case of Turkey", Democratization, DOI: 10.1080/13510347.2012.674369.

OZEL, I. State-Business Coalitions and Economic Development - Comparative Perspectives from Turkey and Mexico, London: Routledge, forthcoming.

OZEL, I. 2010a. "Islamic Capital and Political Islam in Turkey," Haynes, Jeffrey ed. Religion and Politics in Europe, the Middle East and North Africa, London: Routledge.

OZEL, I. 2003 "Beyond the Orthodox Paradox: The Break-up of State-Business Coalitions in Turkey in the 1980s," Journal of International Affairs, vol.57, no.1, Fall 2003

OZEL, I. and I. Atiyas. 2011 "Regulatory Diffusion in Turkey: A Cross-Sectoral Assessment" (with İzak Atiyas) in T. Çetin and F. Oğuz, eds., The Political Economy of Regulation in Turkey, Springer, forthcoming.

RODRIK, D. 1991. “Premature Liberalization, Incomplete Stabilization: The Özal Debate in Turkey," in Bruno et al. eds, Lessons of Economic Stabilization and Its Aftermath, Cambridge: The MIT Press.

RONIGER, L. 2004. "Political Clientelism, Democracy, and Market Economy," Comparative Politics vol. 36, no. 3 (April 2004), 353-375

SCHNEIDER, B.R. 2009. “Hierarchical Market Economies and Varieties of Capitalism in Latin America," Journal of Latin American Studies, August 2009.

SOCIAL SECURITY INSTITUTION, Republic of Turkey, Statistics.

TURKISH STATISTICAL INSTITUTE (http://www.turkstat.gov.tr/Start. do;jsessionid=GvYIQQpNqNbh3kP1pMTVIhTqVJZCznjym2XyJNnJFJhcPNtXQYWh!388152560)

STOKES, Susan C. 2009. "Political Clientelism," in Carles Boix and Susan C. Stokes (eds.), The Oxford Handbook of Comparative Politics (New York: Oxford University Press, 604-627.

TREASURY STATISTICS, 1980-2003 (http://www.treasury.gov.tr/irj/portal/anonymous?guest_ user=treasury)

WATERBURY, John. 1993. Exposed to Innumerable Delusions, Public Enterprise and State Power in Egypt, India, Mexico and Turkey, New York: Cambridge University Press.

THE WORLDWIDE GOVERNANCE INDiCATORS, The World Bank Group, 2011, (http://info. worldbank.org/governance/wgi/index.asp) 
WORLD DEVELOPMENT INDICATORS (http://data.worldbank.org/data-catalog/worlddevelopment-indicators)

WORLD INVESTMENT REPORT, 2010 and 2011, (http://www.unctad-docs.org/files/UNCTADWIR2011-Full-en.pdf)

UŞAN, M. Fatih, 2009. Türk Sosyal Güvenlik Hukukunun Temel Esasları, 2. Baskı, Ankara.

YURTOĞLU, B. 2000. “Ownership, Control and Performance of Turkish Listed Firms," Emprica, No.27i pp.193-222, Kluwer Academic Publishers, Netherlands.

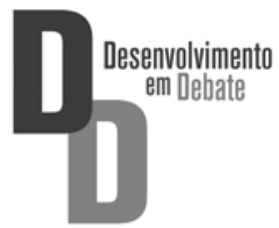

